\title{
Utilization of Electrochemical Sensors and Biosensors in Biochemistry and Molecular Biology
}

\author{
Vojtech Adam ${ }^{1,2}$ and Rene Kizek ${ }^{1 *}$ \\ ${ }^{1}$ Department of Chemistry and Biochemistry and ${ }^{2}$ Department of Animal Nutrition and Forage \\ Production, Mendel University of Agriculture and Forestry, Zemedelska 1, CZ-613 00 Brno, Czech \\ Republic
}

* Author to whom correspondence should be addressed; E-mail: kizek@sci.muni.cz

Received: 25 September 2008 / Accepted: 26 September 2008 / Published: 1 October 2008

A special issue of Sensors entitled "Utilization of Electrochemical Sensors and Biosensors in Biochemistry and Molecular Biology" has been prepared over a period of three years. In this Editorial Note we would like to highlight one of the possible directions for electrochemical sensor and biosensor research resulting from the ideas of Czechoslovakian Nobel Prize winner Jaroslav Heyrovsky and his colleague Rudolf Brdicka.

\section{Could electrochemistry be employed in biochemistry and molecular biology in the $21^{\text {st }}$ century?}

Cancer, "plague of the world", is a word which brings to mind not only a threat to human health but also a subject of investigation for the broader scientific community (almost 60,000 papers appearing in Web of Science in 2007 included "cancer*" within their article titles, keywords or abstracts, and in particular, almost one hundred of them have been published in Nature). The success of treatment of the disease depends on many factors such as prevention, early and sensitive diagnostics. That means that the sooner a cancer is detected, the better the chances to treat it successfully. A very interesting idea about how we could diagnose a tumour disease was created seventy years ago in Czechoslovakia. This idea will not be forgotten.

Rudolf Brdicka, who was born one hundred years ago, published in Nature in 1937 his discoveries concerning the use of polarography to diagnose a tumour disease [1,2]. He discovered a sensitive polarographic "protein effect", conspicuously exhibited by serum, which he explained as due to the catalytic activity of the sulphydryl groups of proteins. The "protein effect" consisted of the appearance of a characteristic wave on the current voltage curve, which was always found to be larger in normal serum samples than when the same procedure was applied to cancer serum [1,2]. A year ago Brdicka's colleague Jaroslav Heyrovsky, recipient of the 1959 Nobel Prize in Chemistry, published a paper in the same journal, where he summarized results obtained in the field of Polarographic Research on Cancer 
[3]. Heyrovsky believed that this field of study should be of general interest of many scientific groups around the world, but as it turns out he was apparently mistaken, as since then, electrochemistry has been slowly disappearing from tumour disease diagnostics due to the use of more modern analytical chemistry and molecular biology techniques. Thus, this unique and interesting technique has not been used, with several exceptions [4], for over fifty years.

\section{Metallothionein}

Five years ago, we published in Analytical Chemistry a paper describing a highly sensitive determination of a protein - metallothionein [5]. This in itself would not be anything special, if we had not also revealed that this low molecular weight, intracellular, cysteine-rich protein has a certain connection with a tumour disease in the subsequent experiments.

\section{Is it a new possibility how we could diagnose a cancer?}

As we have mentioned above, the sooner the cancer is detected, the better the chances to treat it successfully are. Thus, we used an electrochemical technique to analyse blood serum of patients with tumour diseases, the same way Brdicka did. Using a modified Brdicka reaction we have analyzed blood, blood serum and tumours of patients (more than 150) suffering from different types of cancers (melanoma, breast, lung, thyroid gland, kidney, oesophagus, large intestine, head and neck cancer, and leukaemia) and also blood and blood serum from non-cancer affected subjects. The results obtained show that the content of metallothionein increases markedly in blood and blood serum of the patients. We are the first scientific group in the world to not only quantify metallothionein in human blood serum, but also to report real differences between metallothionein levels of a control tissue and a tumourous one. Moreover, during thorough analysis of the experimental results obtained we found a unique correlation between the voltammogram data and the type of cancer. We called it an "electrochemical fingerprint".

\section{Could electrochemistry really be utilized for cancer diagnostics in the $21^{\text {st }}$ century?}

Could electrochemistry be used in $21^{\text {st }}$ century in addition to other robust techniques such as mass spectrometry, nuclear magnetic resonance and many others? One could raise the objection that this "old technique" cannot compete with these modern methods, but in practice the contrary is the case. The results obtained show that electrochemical techniques could be brought back for the investigation of cancer and could potentially enable easy, fast and low cost cancer diagnostics. It is thus possible that the wishes of Jaroslav Heyrovsky and his follower and colleague Rudolf Brdicka will be fulfilled and this auspicious field of cancer study will be developed intensively, not only in Czech laboratories but also around the world.

\section{Special issue "Utilization of Electrochemical Sensors and Biosensors in Biochemistry and Molecular Biology"}

The special issue of Sensors contains more than thirty articles or reviews reporting on various fields of biological research. Experimental papers devoted to environmental stress at plants pay attention to 
the study of the influence of heavy metals on plant species and embryos. The most important feature of these papers was their multi-instrumental approach to find complex reactions of plants under stress [610]. Such a multi-instrumental approach was also employed in the paper reporting a non-destructive evaluation of historical papers [11].

Figure 1. Picture of plants cultivated in an environmental chamber under controlled conditions.

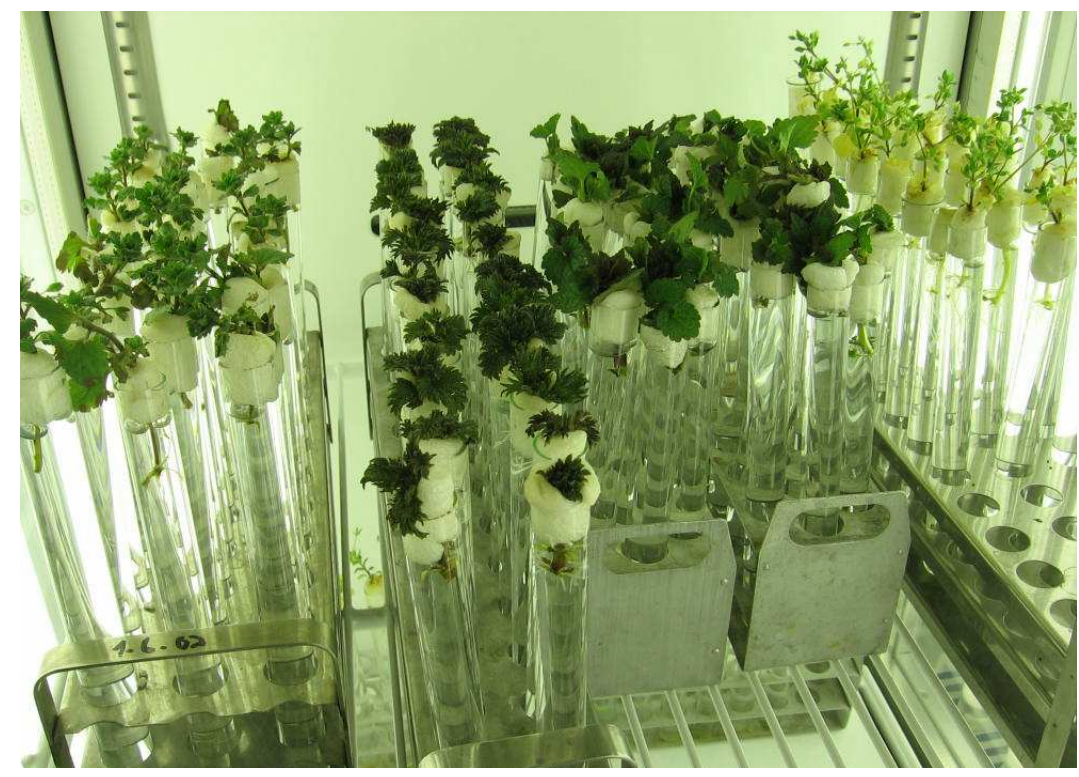

Figure 2. Schematic of environmental monitoring using biosensors.

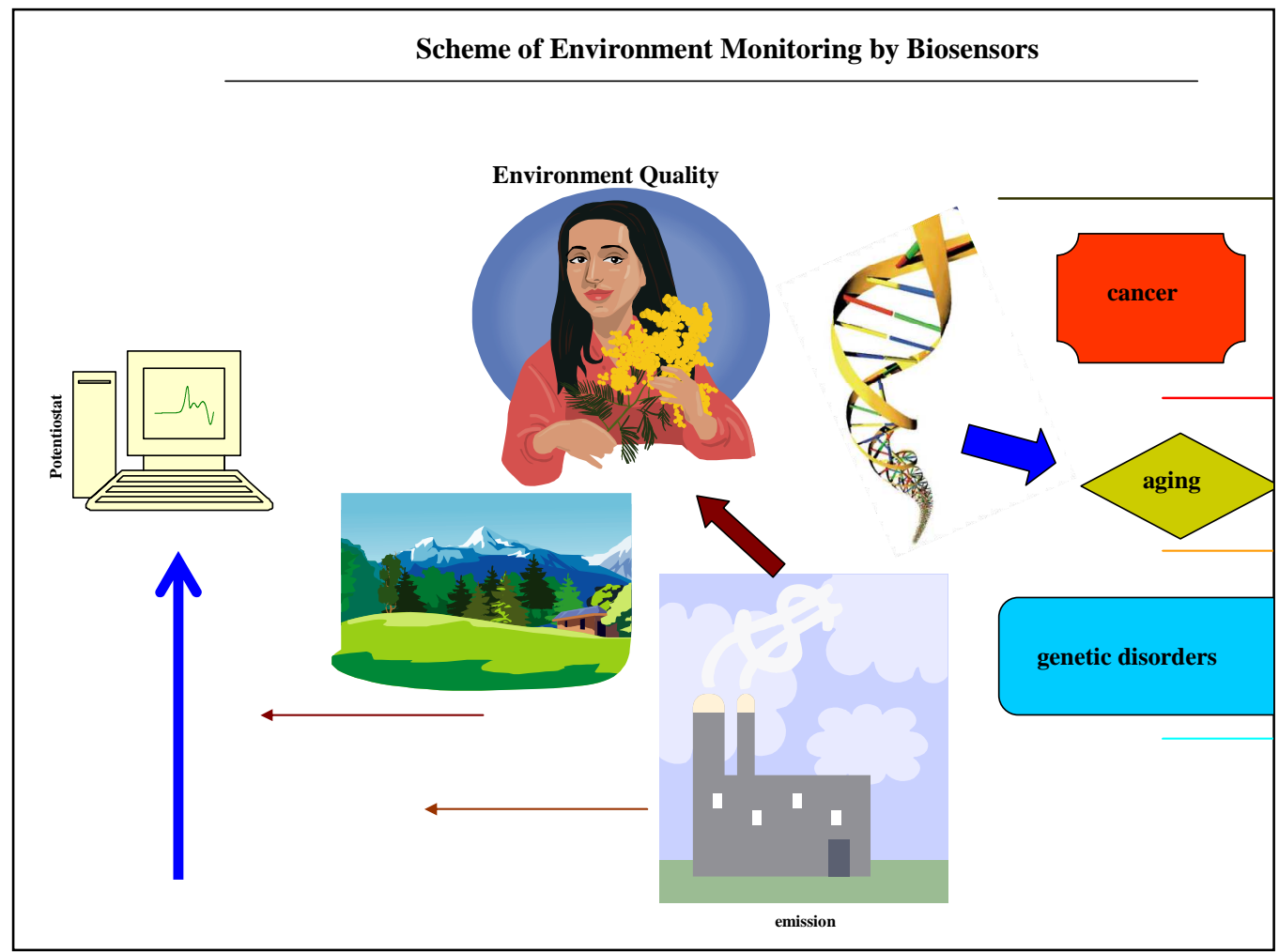

Several papers report the use of miniaturized electrodes or miniaturized particles coupled with various detection techniques for the study of biochemical events and pathways [12-17]. As we mentioned at the beginning of this contribution, electrochemical techniques can be used in the 
diagnosis of tumour diseases $[18,19]$. Moreover, these techniques can be also utilized for investigation of the interaction of anticancer drugs with various biologically active compounds, including glutathione, metallothionein and others [20, 21]. Attention was also paid to toxic substances such as bromadiolone, whch belongs to a group of second-generation anticoagulant rodenticides [22]. Other authors paid attention to the idea of using piezoelectric biosensors for a simple serological diagnosis of tularemia in hares [23]. Three papers were also published in which the authors used biochemical markers to study environmental pollution [24-26]. Similarly to these, new approaches and procedures to analyse cells and their behaviour were suggested [27].

Fruits and vegetables belong to the most important and crucial parts of human diet due to their health benefits. Plant tissues are rich in nutritionally or therapeutically active compounds, which are obviously products of plant secondary metabolism. Analysis of such compounds is therefore both important and needed. Moreover, new compounds belonging to the group of biologically active ones are continuosly being discovered. Sensor and biosensor research is also aimed at the developmenmt of easy-to-use and low cost detection of these substances [28-35].

Detection of nucleic acids is also of current interest, most of all due to recognition of their specific sequences. Approaches for studying nucleic acids, their interactions and modifications can differ, as shown in other papers published in the special issue [36-40].

\section{Acknowledgements}

Rene Kizek and Vojtech Adam would like to express their great thanks to Mr. Matthias Burkhalter, Dr. Shu-Kun Lin and others for their great support and for giving us the opportunity to prepare this Special Issue.

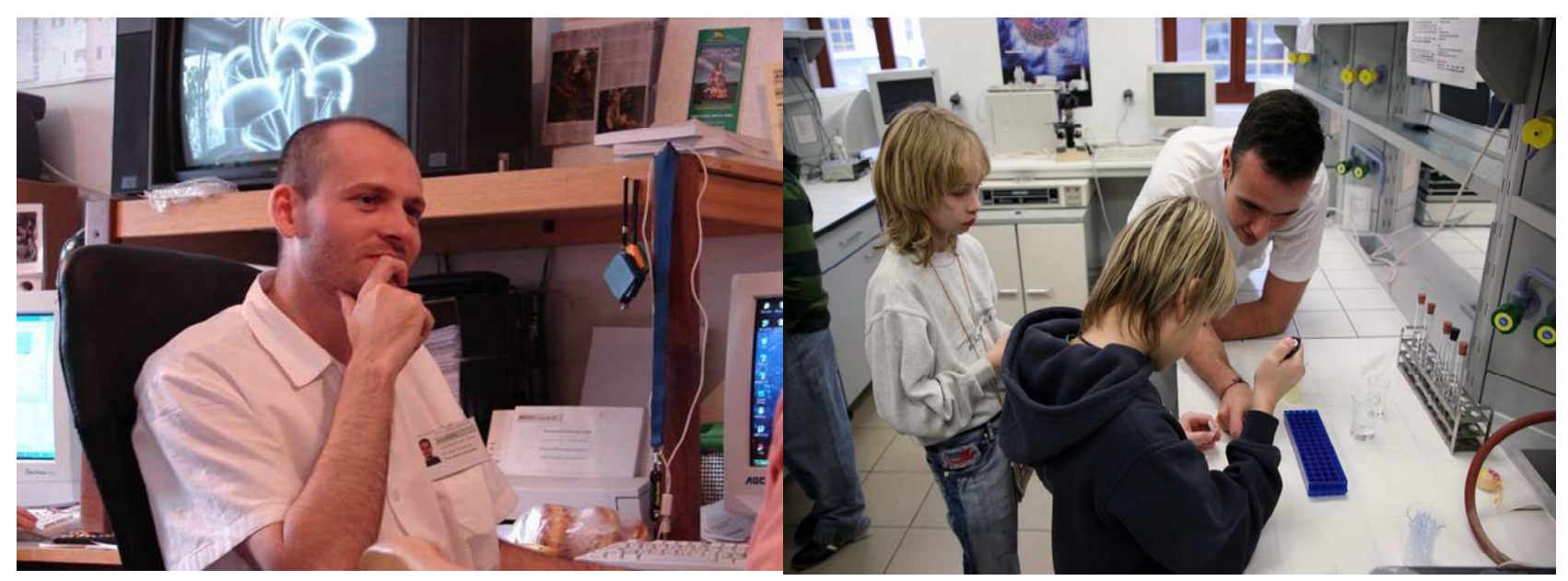

\section{References}

1. Brdicka, R. Application of the polarographic effect of proteins in cancer diagnosis. Nature 1937, 139, 330-330.

2. Brdicka, R. Polarographic investigations in serological cancer diagnosis. Nature 1937, 139, 10201021. 
3. Heyrovsky, J. Polarographic research in cancer. Nature 1938, 142, 317-319.

4. Olafson, R.W.; Sim, R.G. Electrochemical approach to quantitation and characterization of metallothioneins. Anal. Biochem. 1979, 100, 343-351.

5. Kizek, R.; Trnkova, L.; Palecek, E. Determination of metallothionein at the femtomole level by constant current stripping chronopotentiometry. Anal. Chem. 2001, 73, 4801-4807.

6. Supalkova, V.; Huska, D.; Diopan, V.; Hanustiak, P.; Zitka, O.; Stejskal, K.; Baloun, J.; Pikula, J.; Havel, L.; Zehnalek, J.; Adam, V.; Trnkova, L.; Beklova, M.; Kizek, R. Electroanalysis of plant thiols. Sensors 2007, 7, 932-959.

7. Supalkova, V.; Petrek, J.; Baloun, J.; Adam, V.; Bartusek, K.; Trnkova, L.; Beklova, M.; Diopan, V.; Havel, L.; Kizek, R. Multi-instrumental investigation of affecting of early somatic embryos of spruce by cadmium(II) and lead(II) ions. Sensors 2007, 7, 743-759.

8. Adam, V.; Beklova, M.; Pikula, J.; Hubalek, J.; Trnkova, L.; Kizek, R. Shapes of differential pulse voltammograms and level of metallothionein at different animal species. Sensors 2007, 7, 2419-2429.

9. Krizkova, S.; Ryant, P.; Krystofova, O.; Adam, V.; Galiova, M.; Beklova, M.; Babula, P.; Kaiser, J.; Novotny, K.; Novotny, J.; Liska, M.; Malina, R.; Zehnalek, J.; Hubalek, J.; Havel, L.; Kizek, R. Multi-instrumental analysis of tissues of sunflower plants treated with silver(I) ions - Plants as bioindicators of environmental pollution. Sensors 2008, 8, 445-463.

10. Ryant, P.; Dolezelova, E.; Fabrik, I.; Baloun, J.; Adam, V.; Babula, P.; Kizek, R. Electrochemical determination of low molecular mass thiols content in potatoes (Solanum tuberosum) cultivated in the presence of various sulphur forms and infected by late blight (Phytophora infestans). Sensors 2008, 8, 3165-3182.

11. Strlic, M.; Cigic, I.K.; Kolar, J.; de Bruin, G.; Pihlar, B. Non-destructive evaluation of historical paper based on pH estimation from VOC emissions. Sensors 2007, 7, 3136-3145.

12. Vestergaard, M.; Kerman, K.; Tamiya, E. An overview of label-free electrochemical protein sensors. Sensors 2007, 7, 3442-3458.

13. Hubalek, J.; Hradecky, J.; Adam, V.; Krystofova, O.; Huska, D.; Masarik, M.; Trnkova, L.; Horna, A.; Klosova, K.; Adamek, M.; Zehnalek, J.; Kizek, R. Spectrometric and voltammetric analysis of urease - nickel nanoelectrode as an electrochemical sensor. Sensors 2007, 7, 1238-1255.

14. Hu, J.Q.; Wang, Z.P.; Li, J.H. Gold nanoparticles with special shapes: Controlled synthesis, surface-enhanced Raman scattering, and the application in biodetection. Sensors 2007, 7, 32993311.

15. Yogeswaran, U.; Chen, S.M. A review on the electrochemical sensors and biosensors composed of nanowires as sensing material. Sensors 2008, 8, 290-313.

16. Satoh, W.; Hosono, H.; Yokomaku, H.; Morimoto, K.; Upadhyay, S.; Suzuki, H. Integrated electrochemical analysis system with microfluidic and sensing functions. Sensors 2008, 8, 11111127.

17. Wang, Y.; Xu, H.; Zhang, J.; Li, G. A Review of Electrochemical Sensors for Clinic Analysis. Sensors 2008, 8, 2043-2081.

18. Adam, V.; Baloun, J.; Fabrik, I.; Trnkova, L.; Kizek, R. An electrochemical detection of metallothioneins in nanolitres at zeptomole level. Sensors 2008, 8, 2293-2305. 
19. Krizkova, S.; Fabrik, I.; Adam, V.; Kukacka, J.; Prusa, R.; Chavis, G.J.; Trnkova, L.; Strnadel, J.; Horak, V.; Kizek, R. Utilizing of adsorptive transfer stripping technique Brdicka reaction for determination of metallothioneins level in melanoma cells, blood serum and tissues. Sensors $\mathbf{2 0 0 8}$, 8, 3106-3122.

20. Zitka, O.; Huska, D.; Krizkova, S.; Adam, V.; Chavis, G.J.; Trnkova, L.; Horna, A.; Hubalek, J.; Kizek, R. An investigation of glutathione-platinum(II) interactions by means of the flow injection analysis using glassy carbon electrode. Sensors 2007, 7, 1256-1270.

21. Adam, V.; Zitka, O.; Dolezal, P.; Zeman, L.; Horna, A.; Hubalek, J.; Sileny, J.; Krizkova, S.; Trnkova, L.; Kizek, R. Lactoferrin isolation using monolithic column coupled with spectrometric or micro-amperometric detector. Sensors 2008, 8, 464-487.

22. Krizkova, S.; Beklova, M.; Pikula, J.; Adam, V.; Horna, A.; Kizek, R. Hazards of secondary bromadiolone intoxications evaluated using high-performance liquid chromatography with electrochemical detection. Sensors 2007, 7, 1271-1286.

23. Pohanka, M.; Treml, F.; Hubalek, M.; Band'ouchova, H.; Beklova, M.; Pikula, J. Piezoelectric biosensor for a simple serological diagnosis of tularemia in infected European brown hares (Lepus europaeus). Sensors 2007, 7, 2825-2834.

24. Havelkova, M.; Randak, T.; Zlabek, V.; Krijt, J.; Kroupova, H.; Pulkrabova, J.; Svobodova, Z. Biochemical markers for assessing aquatic contamination. Sensors 2007, 7, 2599-2611.

25. Huska, D.; Krizkova, S.; Beklova, M.; Havel, L.; Zehnalek, J.; Diopan, V.; Adam, V.; Zeman, L.; Babula, P.; Kizek, R. Influence of cadmium(II) ions and brewery sludge on metallothionein level in earthworms (Eisenia fetida) - Biotransforming of toxic wastes. Sensors 2008, 8, 1039-1047.

26. Havelkova, M.; Blahova, J.; Kroupova, H.; Randak, T.; Slatinska, I.; Leontovycova, D.; Grabic, R.; Pospisil, R.; Svobodova, Z. Biomarkers of contaminant exposure in Chub (Leuciscus cephalus L.) - a biomonitoring of major rivers in the Czech Republic Sensors 2008, 8, 2589-2603.

27. Cho, S.; Castellarnau, M.; Samitier, J.; Thielecke, H. Dependence of impedance of embedded single cells on cellular behaviour. Sensors 2008, 8, 1198-1211.

28. Adam, V.; Mikelova, R.; Hubalek, J.; Hanustiak, P.; Beklova, M.; Hodek, P.; Horna, A.; Trnkova, L.; Stiborova, M.; Zeman, L.; Kizek, R. Utilizing of square wave voltammetry to detect flavonoids in the presence of human urine. Sensors 2007, 7, 2402-2418.

29. Kumar, S.A.; Chen, S.M. Electroanalysis of NADH using conducting and redox active polymer/carbon nanotubes modified electrodes - A review. Sensors 2008, 8, 739-766.

30. Belluzo, M.S.; Ribone, M.E.; Lagier, C.M. Assembling amperometric biosensors for clinical diagnostics. Sensors 2008, 8, 1366-1399.

31. Grieshaber, D.; MacKenzie, R.; Voros, J.; Reimhult, E. Electrochemical biosensors - Sensor principles and architectures. Sensors 2008, 8, 1400-1458.

32. Arvinte, A.; Rotariu, L.; Bala, C. Amperometric low-potential detection of malic acid using single-wall carbon nanotubes based electrodes. Sensors 2008, 8, 1497-1507.

33. Huang, F.; Peng, Y.Y.; Jin, G.Y.; Zhang, S.; Kong, J.L. Sensitive detection of haloperidol and hydroxyzine at multi-walled carbon nanotubes-modified glassy carbon electrodes. Sensors $\mathbf{2 0 0 8}$, 8, 1879-1889. 
34. Ming, L.; Xi, X.; Chen, T.T.; Liu, J. Electrochemical determination of trace Sudan I contamination in chili powder at carbon nanotube modified electrodes. Sensors 2008, 8, 1890-1900.

35. Mavrikou, S.; Flampouri, K.; Moschopoulou, G.; Mangana, O.; Michaelides, A.; Kintzios, S. Assessment of Organophosphate and Carbamate Pesticide Residues in Cigarette Tobacco with a Novel Cell Biosensor. Sensors 2008, 8, 2818-2832.

36. Pan, D.; Zuo, X.L.; Wan, Y.; Wang, L.H.; Zhang, J.; Song, S.P.; Fan, C.H. Electrochemical interrogation of interactions between surface-confined DNA and methylene blue. Sensors 2007, 7, 2671-2680.

37. Horakova-Brazdilova, P.; Fojtova, M.; Vytras, K.; Fojta, M. Enzyme-linked electrochemical detection of PCR-amplified nucleotide sequences using disposable screen-printed sensors. Applications in gene expression monitoring. Sensors 2008, 8, 193-210.

38. Hwang, E.T.; Ahn, J.M.; Kim, B.C.; Gu, M.B. Construction of a nrdA :: luxCDABE fusion and its use in Escherichia coli as a DNA damage biosensor. Sensors 2008, 8, 1297-1307.

39. de Abreu, F.C.; de Paula, F.S.; Ferreira, D.C.M.; Nascimento, V.B.; Santos, A.M.C.; Santoro, M.M.; Salas, C.E.; Lopes, J.C.D.; Goulart, M.O.F. The application of DNA-biosensors and

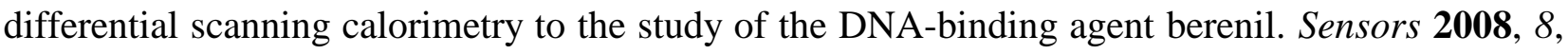
1519-1538.

40. Trnkova, L.; Zerzankova, L.; Dycka, F.; Mikelova, R.; Jelen, F. Study of copper and purinecopper complexes on modified carbon electrodes by cyclic and elimination voltammetry. Sensors 2008, 8, 429-444.

(C) 2008 by the authors; licensee Molecular Diversity Preservation International, Basel, Switzerland. This article is an open-access article distributed under the terms and conditions of the Creative Commons Attribution license (http://creativecommons.org/licenses/by/3.0/). 